\title{
Performance of Field Pea and Lentil When Intercropped With Faba Bean and Chickpea in the Peace River Region of Alberta, Canada
}

\author{
Kabal Singh Gill ${ }^{1} \&$ Darcy Boisvert ${ }^{1}$ \\ ${ }^{1}$ SARDA Ag Research, Falher, Alberta, Canada \\ Correspondence: Kabal S. Gill, SARDA Ag Research, 701 Main Street, Box 90, Falher, Alberta T0H 1M0, \\ Canada. Tel: 1-780-837-1143. E-mail: consultant@sarda.ca
}

Received: December 29, 2019

Accepted: February 10, 2020

Online Published: March 15, 2020

doi:10.5539/jas.v12n4p1

URL: https://doi.org/10.5539/jas.v12n4p1

\begin{abstract}
Research information concerning intercropping legumes with non-legumes for seed production is extensively available, but concerning legume-legume intercropping is from tropical areas only. Field pea and lentil tend to lodge as they reach maturity and this can result in harvesting difficulties as well as reduced seed yield and quality. The objectives of this study were to assess crop response and seed production when field pea (Pisum staivum L.) and lentil (Lens culinaris Medic.) were intercropped with lodging resistant faba bean (Vicia faba L.) and chickpea (Cicer arietinum L.), in the Peace River region of Alberta, Canada. The combinations of lentil+faba bean, lentil+chickpea, field pea+faba bean and field pea+chickpea intercrops; and their sole crops were tested in 2015, 2016 and 2017. Seeding rates were either 75 or $100 \%$ of lentil and field pea; and either 50 or $75 \%$ of faba bean and chickpea for intercrops; and $100 \%$ for sole crops. Compared to the seed rates in the intercrops, the plant counts were similar or slightly lower for lentil and field pea sole crops, while they were similar or lower for faba bean and chickpea sole crops. Plant height of lentil and field pea was similar in sole crops and intercrops, while faba bean and chickpea were stunted in some intercrop treatments. There was reduced lodging of lentil and field pea in the intercrops compared to sole crops in 2016 and 2017, which could provide better harvesting conditions. Compared to sole crops, the seed yield and land equivalent ratio (LER) of individual crops in the intercropping treatments were similar or slightly lower than the seeding rates for lentil and field pea, while they were similar or noticeably lower for faba bean and chickpea. There was very little gain in the total seed yield and total LER values from the intercrops in 2015, due to very dry weather conditions. However with adequate rain in 2016 and 2017, the lentil intercrops provided greater total seed yield and total LER than the sole crops, but the gains in the total seed yield and total LER from the field pea intercrops over the sole field pea were small and not consistent. Overall, the results indicate a potential for improving seed yield and total LER over the sole crops of lentil by intercropping with faba bean and chickpea.
\end{abstract}

Keywords: chickpea, faba bean, field pea, intercropping, land equivalent ratio, lentil, seed yield

\section{Introduction}

Intercropping generally refers to growing two or more crops together in the same field and can have many benefits. A frequently reported advantage is greater total seed yield produced by intercrops than the sole crops on the same land area. The reasons for increased yield in intercropping systems include weed suppression (Carr et al., 1995; Poggio, 2005), and decreased susceptibility to insects and diseases (Helenius, 1991; Paras \& Chakravorty, 2005; Chen et al., 2007). It has also been suggested that a mixture of different crop types will utilize resources (such as nutrients, water and light) more efficiently than sole crops. This is due to differences in root systems and benefits to other crops from the nitrogen (N) fixed by legumes (Izaurralde et al., 1992; Hauggaard-Nielsen et al., 2001, 2006). Increased light interception due to greater canopy cover results in higher biomass production in intercrops when compared to sole crops, which in turn produces greater seed production (Kushwaha \& De, 1987; Morris \& Garrity, 1993).

The agronomic and economic benefits resulting from intercropping legumes with other crops for yield, nutrient uptake and economic returns have varied between crop species, soil types and climatic conditions (agro-ecological regions). Intercropping barley (Hordeum vulgare L.) and field pea (Pisum staivum L.) can result in improved 
stability of production and lower risk of crop failure by adding diversity to the cropping system (Jensen, 1996; Hauggaard-Nielsen et al., 2001), reduced input costs by lowering $\mathrm{N}$ fertilizer and pesticide requirements, and thus increase economic returns (Aktar et al., 1993; Hauggaard-Nielsen \& Jensen, 2001). Szczukowski (1989) and Carr et al. (1995) showed improved harvest ability in cereal-field pea and cereal-lentil (Lens culinaris Medic.) intercrops. Knudson et al. (2004) suggested that the total N concentration in a barley crop increases when it is grown as a mixture with field pea, due to a lack of competition for $\mathrm{N}$ between these crops. The total $\mathrm{N}$ increase in canola (Brassica napus L.) seed in a canola-field pea intercrop was due to the $\mathrm{N}$ fixed by field pea that was available to the canola plant (Malhi, 2012).

Oilseed-legume intercropping led to increased yield (Aktar et al., 1993; Jetendra \& Mishra, 1999) and improved grain quality (Zielinska \& Rutkowski, 1988; Szczukowski, 1989). Compared to the respective sole crops, the canola-field pea intercrops had seed yields of $81-84 \%$ for field pea and $56-69 \%$ for canola, with greater total seed yield and higher total land equivalent ratio $\left(\mathrm{LER}_{\mathrm{T}}\right)$ values from intercrops than sole crops (Malhi, 2012). Also, there was more $\mathrm{N}$ uptake in the intercrops than sole crops, and the total $\mathrm{LER}_{\mathrm{T}}$ values of the canola-field pea intercrops were higher when no $\mathrm{N}$ was applied compared to intercrops with $\mathrm{N}$ fertilization. The higher $\mathrm{LER}_{\mathrm{T}}$ values of intercrops than sole crops indicates superior use of different $\mathrm{N}$ sources and possibly other nutrients when root systems of non-legume and legume crops are intermixed (Martin \& Snaydon, 1982). Similar results were reported previously from intercropping systems for mixed cultures of barley and field pea (Jensen, 1996; Chen et al., 2004) and oilseed rape/canola/mustard with field pea (Aktar et al., 1993; Jetendra \& Mishra, 1999). In summary, intercrops of oilseeds with field pea improved crop yield, $\mathrm{N}$ uptake, net returns, and reduced land requirements compared to sole crops of canola or field pea.

Double-up legume technology (legume-legume intercrops) has been proposed as a cost-effective fertility management practice in Malawi (ICRISAT/MAI, 2000). Research on intercropping legumes only has included soybean (Glycine max L.), pigeon pea (Cajanus cajan), cowpea (Vigna unguiculata) and groundnut (Arachis hypogaea) crops in the tropical environments. Ghosh et al. (2006) reported higher seed yield, net returns and benefit:cost ratio from the soybean-pigeon pea intercrops over both sole pigeon pea and soybean stands, and also higher energy output and energy use efficiency over sole soybean. Higher nitrogen fixation was observed from groundnut-pigeon pea over the sole pigeon pea and sole groundnut, but not from the soybean-pigeon pea system over the sole soybean or sole pigeon pea (Nijra et al. 2012).

Though preceding literature review show considerable research information on improved seed yield from intercropping legumes with non-legumes that include the Canadian Prairies, there is lack of research information on the performance of legume-legume intercrops in the Canadian Prairies. Intercropping legumes only would aim for improved yield potential without the need for $\mathrm{N}$ fertilizer application, which becomes an issue when legumes and other crop types are intercropped. This system also provides potential of herbicide use for weed management throughout the cropping season, especially targeting grassy weeds.

Field pea and lentil tend to lodge as they reach maturity, which can result in increased difficulties and seed losses during harvest, which contributes to reduced seed yield and quality. Faba bean (Vicia faba L.) and chickpea (Cicer arietinum L.) are more resistant to lodging, and therefore intercropping them with field pea and lentil may reduce lodging, minimize harvest ability issues, and increase total seed production. The objective of this study was to assess crop response and seed production when field pea and lentil were intercropped with faba bean and chickpea.

\section{Materials and Methods}

\subsection{Site, Soil and Weather}

Small plot field trials were conducted near Donnelly in the southeast Peace River Region of Alberta, Canada $\left(55^{\circ} 39^{\prime} 38.43^{\prime \prime} \mathrm{N} ; 117^{\circ} 6^{\prime} 10.64^{\prime \prime} \mathrm{W}\right)$. The area has a subarctic climate (boreal climate), which is characterized by cold long winters, and cool to mild short summers. Soil at the site was a clay loam Luvisol (Soil Classification Working Group, 1998). Selected properties of 0-15 cm soil are presented in Table 1. Rainfall data (Table 2) were collected from the Ballater weather station located about $6 \mathrm{~km}$ west of the experimental site (Alberta Agriculture and Forestry, 2018). 
Table 1. Properties of the $0-15 \mathrm{~cm}$ soil at the experimental site in 2015, 2016 and 2017

\begin{tabular}{|c|c|c|c|c|c|c|c|}
\hline Year & CEC & Organic & $\mathrm{pH}$ & $\mathrm{NO}_{3}-\mathrm{N}$ & $\mathrm{P}$ & $\mathrm{K}$ & $\mathrm{SO}_{4}-\mathrm{S}$ \\
\hline & $\mathrm{m}$ eq. $100 \mathrm{~g}^{-1}$ & Matter, \% & (water) & \multicolumn{4}{|c|}{ 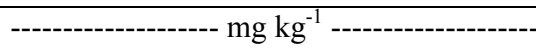 } \\
\hline 2015 & 22.8 & 6.2 & 6.9 & 14.0 & 10.0 & 109 & 21.0 \\
\hline 2016 & 18.6 & 5.5 & 5.6 & 9.0 & 31.0 & 251 & 15.0 \\
\hline 2017 & 13.6 & 5.0 & 6.3 & 11.0 & 12.0 & 94 & 14.0 \\
\hline
\end{tabular}

Table 2. Monthly rainfall amounts $(\mathrm{mm})$ during the crop growing period of the 2015, 2016 and 2017 study years

\begin{tabular}{lllllll}
\hline Year & May & June & July & Aug. & Sept. & Total \\
\hline 2015 & 19.4 & 34.4 & 28.6 & 44.5 & 34.2 & 161.1 \\
2016 & 70.0 & 21.3 & 59.9 & 62.8 & 58.9 & 299.9 \\
2017 & 64.4 & 45.3 & 53.4 & 44.8 & 66.4 & 274.3 \\
\hline 30 Yr. Average & $\mathbf{4 1 . 2}$ & $\mathbf{7 0 . 4}$ & $\mathbf{6 6 . 5}$ & $\mathbf{5 5 . 8}$ & $\mathbf{3 9 . 6}$ & $\mathbf{2 7 7 . 3}$ \\
\hline
\end{tabular}

\subsection{Treatments and Agronomic Management}

There were 8 treatments in 2015; and 12 treatments in both 2016 and 2017 (Table 3). The treatments were laid out in a Randomized Complete Block Design (RCBD) with four replications. The target seeding rates in sole crops $(100 \%)$ were to obtain 88 plants $\mathrm{m}^{-2}$ for field pea (var. 'CDC Meadow-a yellow cotyledon pea'), 130 plants $\mathrm{m}^{-2}$ for lentil (var. 'CDC Maxim'), 45 plants $\mathrm{m}^{-2}$ for faba bean (var. 'Snowbird') and 50 plants $\mathrm{m}^{-2}$ for chickpea (var. 'CDC Orion'). The actual seeding rates in the intercrop treatments were, either 75 or $100 \%$ of lentil and field pea, and either 50 or $75 \%$ of faba bean and chickpea (Table 3 ).

Crops were direct seeded into cereal stubble using a plot seeder equipped with dual (shallow and deep) knife openers. To effectively seed two crops at the same time in the intercropping treatments, used shallow openers (seeding depth $2.5 \mathrm{~cm}$ ) for smaller seeds (lentil and field pea) and deep openers (seeding depth $3.4 \mathrm{~cm}$ ) for larger seeds (faba bean and chickpea). Seed rows were spaced at $28 \mathrm{~cm}$, and the paired seed rows of two crops in the intercrop plots were $3.8 \mathrm{~cm}$ apart. Same rate of commercial fertilizers (11-51-0;0-0-60;20-0-0-24) were applied to all the treatments in a given year. For the intercrop plots, $50 \%$ of the fertilizer blend was applied with each shank (shallow and deep). Crop specific granular inoculant was applied in the row. Crop from the whole plot $\left(7 \mathrm{~m}^{2}\right)$ was harvested with a plot combine. Desiccation occurred a few days after maturity of lentil and field pea, to allow most faba bean and chickpea seeds to reach physiological maturity. Specific agronomic practices for each trial year are described below.

2015: A pre-seed weed control herbicide glyphosate (445 g a.i. ha ${ }^{-1}$, as Transorb) was applied on May 4. Seeding was done on May 15. All plots received $38 \mathrm{~kg} \mathrm{~N}, 19 \mathrm{~kg} \mathrm{P}, 18 \mathrm{~kg} \mathrm{~K}$ and $34 \mathrm{~kg} \mathrm{~S} \mathrm{ha}^{-1}$ from granular fertilizers. An in-crop application of $0.75 \mathrm{~L} \mathrm{ha}^{-1}$ Assure II (Quizalofop-p-ethyl) herbicide $+1.1 \mathrm{~L} \mathrm{ha}^{-1}$ Sure Mix ( $40 \%$ surfactant blend $+60 \%$ paraffinic petroleum oil) was on June 10. Crops were desiccated with $1.7 \mathrm{~L} \mathrm{ha}^{-1}$ of Reglone Ion on Sept. 7, and harvested on Sept. 21.

2016: A pre-seed burn off was on April 29 (667 g a.i. glyphosate as Tansorb +270 a.i. Bortex ha $\left.{ }^{-1}\right)$. Seeding was done on May 17 and all plots were given $15 \mathrm{~kg} \mathrm{P} \mathrm{ha}^{-1}$ as fertilizer. An in-crop application of $0.75 \mathrm{~L} \mathrm{ha}^{-1}$ Assure II (Quizalofop-p-ethyl) herbicide $+1.1 \mathrm{~L} \mathrm{ha}^{-1}$ Sure Mix (40\% surfactant blend $+60 \%$ paraffinic petroleum oil) was on June 10. Crops were desiccated using 1.7 $\mathrm{L} \mathrm{ha}^{-1}$ of Reglone Ion on Sept. 7, and harvested on Oct. 6.

2017: A pre-seed burn off was on April 29 (667 g a.i. glyphosate $\mathrm{ha}^{-1}$ as Tansorb +270 a.i. Bortex $\left.\mathrm{ha}^{-1}\right)$. Seeding was done on May 19. All plots received $9.4 \mathrm{~kg} \mathrm{~N}, 15 \mathrm{~kg} \mathrm{P}, 23 \mathrm{~kg} \mathrm{~K}$ and $28 \mathrm{~kg} \mathrm{~S} \mathrm{ha}^{-1}$ from fertilizers. No in crop application of herbicides was done. Crops were desiccated with $1.7 \mathrm{~L} \mathrm{ha}^{-1}$ of Reglone Ion on Sept. 25, and harvested on Oct. 6.

\subsection{Data Collection and Analyses}

Data collection included plant counts $\left(1 \mathrm{~m}\right.$ length, 2 rows plot $\left.^{-1}\right)$ after complete emergence; plant height (4 plants $\operatorname{plot}^{-1}$ ), visual lodging rating, and seed yield of each crop. For intercrops, seeds were separated to determine the yield of each crop, using sieves with appropriate openings for the seed mixture. The seed yield data of individual crops from the 2017 field pea-chickpea intercrops were lost and thus not presented.

From the seed yield data, land equivalent ratio (LER) were calculated (Rao \& Wiley, 1980a). Seed yield from a sole crop in a replication was assigned a LER value of one (1). For the intercrop plots, separate LER values for the Crop 1 (LER 1 , for lentil or field pea) and Crop $2\left(\mathrm{LER}_{2}\right.$, faba bean or chickpea) were calculated to assess their 
relative effects on seed yield of each other. Then $L_{E R}$ and $L_{E R}$ were added to calculate $\mathrm{LER}_{\mathrm{T}}$ to compare the intercrops with the sole crops of lentil and field pea. For each intercrop plot in a replication, the $\mathrm{LER}_{1}, \mathrm{LER}_{2}$ and $\mathrm{LER}_{\mathrm{T}}$ values were calculated as below.

$\mathrm{LER}_{\mathrm{T}}=\left(\mathrm{LER}_{1}=\right.$ Crop 1 yield from intercrop/Crop 1 yield from sole crop; lentil or field pea $)+\left(\mathrm{LER}_{2}=\right.$ Crop 2 yield from intercrop/Crop 2 yield from sole crop; faba bean or chickpea)

Data were subjected to an Analyses of Variance (ANOVA), using the ARM (Agriculture Research Management) software (Gylling Data Management Inc., 2015). Treatment means in the used model are computed from ordinary least squares estimates of fixed treatment effects, with the sums of squares computed sequentially from nested model (Schabenberger \& Pierce, 2001). The Least Squared Difference (LSD), Coefficient of Variance (CV), and level of significance are presented in the treatments mean tables (Table $3,4,5,6$ ). The LSD, where $P \leq 0.05$, was used to indicate significant differences between means.

Plant counts, plant heights, seed yield and LER $\left(\mathrm{LER}_{1}\right.$ and $\left.\mathrm{LER}_{2}\right)$ data from the intercrop plots were analysed separately for the Crop 1 (field pea and lentil) and Crop 2 (faba bean and chickpea) in the intercrops along with the data from their sole crops. This was done to assess the relative effects of the Crop 1 and Crop 2 on each other. The total seed yield and $\mathrm{LER}_{\mathrm{T}}$ data from the intercrop plots were used to compare the sole crops of lentil and field pea with their intercrops.

\section{Results}

3.1 Growing Conditions The 2015 growing season was abnormally dry, particularly from May to early July, with May to Sept. rain being less than $60 \%$ of the long term average (Table 2). In 2016, dry conditions prevailed until a few days after seeding. Above normal rain amounts in late May and early June caused temporary flooding of plots and adequate rain was periodically received during the remainder of season. Compared to the long term average, the 2017 season had higher rain amounts in May (157\%) and September (168\%), while the rain amounts were below normal during the June to August months. Total amounts of rain in both 2016 and 2017 was near the long term average, but due to frequent showers (lack of moisture stress) near harvest, the crops (especially chickpea) continued to flower until desiccation.

\subsection{Plant Counts}

For the sole crops, the observed plant counts were adequate for all crops in 2016 and 2017. In 2015 sole crops, the plant counts were near target for faba bean while they were 75 to $78 \%$ of the target for lentil, field pea and chickpea (probably due to drier soil conditions).

Table 3. Percentages of observed plant counts for the lentil/field pea (Crop 1) and faba bean/chickpea (Crop 2) in the intercrop stands of 2015, 2016 and 2017, relative to their observed plant counts in their sole crops as 100\%

\begin{tabular}{|c|c|c|c|c|c|c|}
\hline \multirow{2}{*}{ Crop \& seed rate $\%$} & \multicolumn{2}{|c|}{2015} & \multicolumn{2}{|c|}{2016} & \multicolumn{2}{|c|}{2017} \\
\hline & Crop 1 & Crop 2 & Crop 1 & Crop 2 & Crop 1 & Crop 2 \\
\hline Faba Bean $100 \%$ & $\mathrm{n} / \mathrm{a}^{1}$ & 100 & $\mathrm{n} / \mathrm{a}$ & 100 & $\mathrm{n} / \mathrm{a}$ & 100 \\
\hline Chickpea $100 \%$ & $\mathrm{n} / \mathrm{a}$ & 100 & $\mathrm{n} / \mathrm{a}$ & 100 & $\mathrm{n} / \mathrm{a}$ & 100 \\
\hline Lentil100\% & 100 & $\mathrm{n} / \mathrm{a}$ & 100 & $\mathrm{n} / \mathrm{a}$ & 100 & $\mathrm{n} / \mathrm{a}$ \\
\hline Lentil100\%+Faba Bean50\% & $\mathrm{n} / \mathrm{a}$ & $\mathrm{n} / \mathrm{a}$ & 81.0 & 56.0 & 106.0 & 52.0 \\
\hline Lentil75\%+Faba Bean75\% & 83.1 & 57.4 & 69.7 & 56.5 & 83.0 & 64.0 \\
\hline Lentil100\%+Chickpea $50 \%$ & $\mathrm{n} / \mathrm{a}$ & $\mathrm{n} / \mathrm{a}$ & 87.4 & 53.4 & 101.0 & 18.0 \\
\hline Lentil75\%+Chickpea75\% & 63.2 & 82.0 & 60.2 & 50.1 & 77.0 & 32.5 \\
\hline Field Pea $100 \%$ & 100 & $\mathrm{n} / \mathrm{a}$ & 100 & $\mathrm{n} / \mathrm{a}$ & 100 & $\mathrm{n} / \mathrm{a}$ \\
\hline Field Pea $100 \%+$ Faba Bean $50 \%$ & $\mathrm{n} / \mathrm{a}$ & $\mathrm{n} / \mathrm{a}$ & 91.0 & 44.8 & 93.0 & 51.0 \\
\hline Field Pea $75 \%+$ Faba Bean75\% & 77.9 & 60.1 & 64.0 & 49.6 & 76.0 & 46.0 \\
\hline Field Pea $100 \%+$ Chickpea $50 \%$ & $\mathrm{n} / \mathrm{a}$ & $\mathrm{n} / \mathrm{a}$ & 79.0 & 49.6 & 97.0 & 51.0 \\
\hline Field Pea 75\%+Chickpea75\% & 49.1 & 71.4 & 55.0 & 71.5 & 83.0 & 49.0 \\
\hline$L S D 5 \%$ & 15.7 & 15.1 & 20.6 & 18.3 & 25.2 & 10.2 \\
\hline$C V, \%$ & 17.7 & 17.4 & 4.1 & 5.7 & 13.9 & 15.2 \\
\hline p-value & 0.002 & 0.001 & $<0.001$ & $<0.001$ & $<0.001$ & $<0.001$ \\
\hline
\end{tabular}

Note. ${ }^{1} \mathrm{n} / \mathrm{a}$ refers to not applicable or treatment not tested.

The plant counts in intercrop treatments are presented as a percentage of their sole crop plant counts in given years. The expected plant counts of each crop in intercrop were based on the seeding rate, i.e., the $75 \%$ seeding rate in 
intercrops were expected to result in $75 \%$ plant counts when compared to their values in the sole crops as $100 \%$. This was done to compare the performance of crops in the intercrops to their sole crops, without confounding the effects of seed rates.

Lentil and field pea plant counts in 2015 were lower than expected (75\%) when intercropped with chickpea (63.2\% and $49.1 \%$, respectively) but not when intercropped with faba bean $(83.1 \%$ and $77.9 \%$, respectively) (Table 3$)$. Similarly, the lentil and field pea plant counts in the 2016 intercrop treatments were lower than their $100 \%$ (79.0 to $91.0 \%$ ) and $75 \%$ (55.0 to $69.7 \%$ ) seeding rates. Unlike earlier years, the 2017 plant counts of lentil and field pea in the intercrops were very similar to their seed rates of $100 \%(93.0$ to $106.0 \%)$ and $75 \%(76.0$ to $83.0 \%)$.

Faba bean plant counts in the intercrop treatments were lower (57.4 and 60.1\%) than expected (75\%) in 2015 . Similarly in 2016, plant counts of faba bean were somewhat lower (49.6 and 56.5\%) than expected in their $75 \%$ seeding rate intercrops while they were very similar (44.8 and 56.0\%) to what was expected in the $50 \%$ seeding rate intercrops. The faba bean plant counts in the 2017 intercrops were similar to the expected (52.0 and $51.0 \%)$ for the $50 \%$ seed rate treatments but lower $(46.0$ and $64.0 \%$ ) for the $75 \%$ seed rate treatments.

Chickpea plant counts in the $75 \%$ seeding rate intercrop treatments $(82.0 \%$ and $71.4 \%$ of sole crop) were near expected values with either crop in 2015. Similarly, the 2016 chickpea plant counts in intercrop stands were very similar to their $50 \%$ and $75 \%$ seeding rates, except lower $(50.1 \%)$ than expected $75 \%$ when intercropped with lentil. In 2017, the chickpea plant counts in the intercropped stands were near the $50 \%$ seed rate with field pea $(51.0 \%)$, but were much lower than $50 \%$ seed rates with lentil (18.0\%) and $75 \%$ seed rate with both crops $(32.5$ and $49.0 \%)$.

\subsection{Plant Height and Lodging}

Lentil and field pea plant heights were similar in the sole and intercropped stands in all 3 years, indicating no effect of the faba bean or chickpea crops (Table 4). Faba bean was shorter in the intercrops than the sole crops in all 3 years, with exception of both field pea-faba bean intercrops in 2016 and the field pea $75 \%+$ faba bean $75 \%$ treatment in 2017. Chickpea plant height was similar across all treatments in 2015, whereas it was shorter in the intercrops than the sole crops in 2016 and 2017.

Table 4. Plant height (cm) of the lentil/field pea (Crop 1) and faba bean/chickpea (Crop 2) crops in the sole and intercropped stands of 2015, 2016 and 2017

\begin{tabular}{|c|c|c|c|c|c|c|}
\hline \multirow{2}{*}{ Crop \& Seed Rate $\%$} & \multicolumn{2}{|c|}{2015} & \multicolumn{2}{|c|}{2016} & \multicolumn{2}{|c|}{2017} \\
\hline & Crop 1 & Crop 2 & Crop 1 & Crop 2 & Crop 1 & Crop 2 \\
\hline Faba Bean $100 \%$ & $\mathrm{n} / \mathrm{a}^{1}$ & 52.3 & $\mathrm{n} / \mathrm{a}$ & 72.0 & $\mathrm{n} / \mathrm{a}$ & 91.4 \\
\hline Chickpea $100 \%$ & $\mathrm{n} / \mathrm{a}$ & 29.4 & $\mathrm{n} / \mathrm{a}$ & 54.3 & $\mathrm{n} / \mathrm{a}$ & 69.6 \\
\hline Lentil100\% & 28.8 & $\mathrm{n} / \mathrm{a}$ & 35.7 & $\mathrm{n} / \mathrm{a}$ & 39.4 & $\mathrm{n} / \mathrm{a}$ \\
\hline Lentil100\%+Faba Bean50\% & $\mathrm{n} / \mathrm{a}$ & $\mathrm{n} / \mathrm{a}$ & 36.3 & 62.5 & 45.7 & 72.6 \\
\hline Lentil75\%+Faba Bean75\% & 26.7 & 40.2 & 37.8 & 64.2 & 43.2 & 78.5 \\
\hline Lentil100\%+Chickpea $50 \%$ & $\mathrm{n} / \mathrm{a}$ & $\mathrm{n} / \mathrm{a}$ & 37.0 & 46.7 & 40.3 & 53.4 \\
\hline Lenti175\%+Chickpea $75 \%$ & 26.7 & 27.5 & 34.2 & 49.7 & 39.4 & 54.1 \\
\hline Field Pea $100 \%$ & 53.0 & $\mathrm{n} / \mathrm{a}$ & 72.0 & $\mathrm{n} / \mathrm{a}$ & 93.8 & $\mathrm{n} / \mathrm{a}$ \\
\hline Field Pea $100 \%+$ Faba Bean $50 \%$ & $\mathrm{n} / \mathrm{a}$ & $\mathrm{n} / \mathrm{a}$ & 72.0 & 71.2 & 93.6 & 84.1 \\
\hline Field Pea75\%+Faba Bean75\% & 56.4 & 41.9 & 70.2 & 69.4 & 96.4 & 91.1 \\
\hline Field Pea $100 \%+$ Chickpea $50 \%$ & $\mathrm{n} / \mathrm{a}$ & $\mathrm{n} / \mathrm{a}$ & 68.1 & 53.6 & 89.7 & 50.6 \\
\hline Field Pea $75 \%+$ Chickpea $75 \%$ & 51.1 & 29.0 & 67.3 & 46.2 & 93.2 & 56.2 \\
\hline$L S D 5 \%$ & 4.67 & 5.28 & 5.21 & 5.66 & 6.18 & 7.00 \\
\hline$C V, \%$ & 7.7 & 9.5 & 6.8 & 6.6 & 6.1 & 6.9 \\
\hline p-value & 0.001 & 0.001 & $<0.001$ & $<0.001$ & $<0.001$ & $<0.001$ \\
\hline
\end{tabular}

Note. ${ }^{1}$ n/a refers to not applicable or treatment not tested.

Observations taken at physiological maturity indicated no lodging in 2015 (data not presented). Reduced lodging of the lentil and field pea was observed in the intercrops when compared to the sole crops in 2016 and 2017.

\subsection{Seed Yield and Maturity}

\subsubsection{Lentil and Field Pea}


Seed yield of lentil in 2015 intercrops, with $75 \%$ seeding rate, was less than the sole crop, but a significant reduction was realized only for the lentil-chickpea intercrop (Table 5). Like 2015, the seed yield of lentil with both the $100 \%$ and $75 \%$ seeding rates in 2016 intercrops was lower than the sole crop, but with significant reduction in the lentil $75 \%+$ chickpea $75 \%$ intercrop only. In 2017, seed yield of lentil in the intercrop treatments ranged from 85 to $107 \%$ of the sole crop, and was not significantly different from the sole crop even at the $75 \%$ seeding rate of lentil. In all the three years, lentil seed yield reduction in the intercrops was somewhat more severe by chickpea than faba bean.

Table 5. Seed yield $\left(\mathrm{kg} \mathrm{ha}^{-1}\right)$ for the lentil/field pea (Crop 1) and faba bean/chickpea (Crop 2) from their sole and intercropped stands in 2015, 2016 and 2017. Total seed yield from these stands is the sum from Crop 1 and Crop 2

\begin{tabular}{|c|c|c|c|c|c|c|c|c|c|}
\hline \multirow{2}{*}{ Crop \& seed rate $\%$} & \multicolumn{3}{|c|}{2015} & \multicolumn{3}{|c|}{2016} & \multicolumn{3}{|c|}{2017} \\
\hline & Crop1 & Crop2 & Total & Crop1 & Crop2 & Total & Crop1 & Crop2 & Total \\
\hline Faba Bean $100 \%$ & 0.00 & 2084 & 2084 & 0.00 & 4668 & 4668 & 0.00 & 4852 & 4852 \\
\hline Chickpea $100 \%$ & 0.00 & 2118 & 2118 & 0.00 & 3689 & 3689 & 0.00 & 1324 & 1324 \\
\hline Lentil100\% & 1090 & 0 & 1090 & 1685 & 0 & 1685 & 2340 & 0 & 2340 \\
\hline Lentil100\%+Faba Bean $50 \%$ & $\mathrm{n} / \mathrm{a}^{1}$ & $\mathrm{n} / \mathrm{a}$ & $\mathrm{n} / \mathrm{a}$ & 1496 & 2044 & 3540 & 2190 & 1708 & 3898 \\
\hline Lentil $75 \%+$ Faba Bean $75 \%$ & 841 & 547 & 1388 & 1342 & 2519 & 3861 & 1988 & 2660 & 4648 \\
\hline Lentil100\%+Chickpea $50 \%$ & $\mathrm{n} / \mathrm{a}$ & $\mathrm{n} / \mathrm{a}$ & $\mathrm{n} / \mathrm{a}$ & 1320 & 2200 & 3520 & 2515 & 154 & 2669 \\
\hline Lenti175\%+Chickpea $75 \%$ & 556 & 861 & 1417 & 1028 & 2316 & 3344 & 2297 & 251 & 2548 \\
\hline Field Pea $100 \%$ & 2136 & 0.00 & 2136 & 3723 & 0.00 & 3723 & 5856 & 0.00 & 5856 \\
\hline Field Pea $100 \%+$ Faba bean $50 \%$ & $\mathrm{n} / \mathrm{a}$ & $\mathrm{n} / \mathrm{a}$ & $\mathrm{n} / \mathrm{a}$ & 3007 & 1277 & 4284 & 4919 & 588 & 5507 \\
\hline Field pea $75 \%+$ Faba Bean $75 \%$ & 1980 & 316 & 2296 & 2664 & 1441 & 4105 & 4726 & 1134 & 5860 \\
\hline Field Pea $100 \%+$ Chickpea $50 \%$ & $\mathrm{n} / \mathrm{a}$ & $\mathrm{n} / \mathrm{a}$ & $\mathrm{n} / \mathrm{a}$ & 3558 & 1246 & 4804 & $\mathrm{nd}^{\mathrm{b}}$ & nd & 6002 \\
\hline Field Pea $75 \%+$ Chickpea $75 \%$ & 1531 & 496 & 2027 & 2612 & 1447 & 4059 & nd & nd & 6168 \\
\hline$L S D 5 \%$ & 339.8 & 433.4 & 368.7 & 421.5 & 498.4 & 525.8 & 404.5 & 358.6 & 457.1 \\
\hline $\mathrm{CV}, \%$ & 16.6 & 22.3 & 13.6 & 13.1 & 3.4 & 9.7 & 8.2 & $8.3 t$ & 7.4 \\
\hline p-value & 0.001 & 0.001 & $<0.001$ & $<0.001$ & 0.001 & $<0.001$ & $<0.001$ & $<0.001$ & $<0.001$ \\
\hline
\end{tabular}

Note. ${ }^{\mathrm{a}} \mathrm{n} / \mathrm{a}$ refers to not applicable or treatment not tested.

${ }^{\mathrm{b}}$ nd refers to not determined as the seed yield data of individual crops from the field pea-chickpea intercrops were lost.

Field pea seed yield was less in the 2015 intercrops than sole crop, but with a significant reduction only when intercropped with chickpea. The 2016 field pea seed yield in intercrops was significantly lower than the sole crop, for both the $100 \%$ and $75 \%$ seeding rates with faba bean, and for only $75 \%$ seeding rate intercrop with chickpea. Field pea seed yield in 2017 was significantly lower than sole crop in both the $100 \%$ and $75 \%$ seeding rate intercrop treatments with faba bean. Unlike lentil, field pea seed yield reduction was similar for the faba bean or chickpea intercrops.

As expected, the reduction in seed yield of lentil and field pea in intercrops was less for their $100 \%$ than $75 \%$ seed rate. Thus to minimize seed yield reduction in intercrops, $100 \%$ seed rate of lentil and field pea is suggested.

The seeds of lentil and field pea had fully matured in both sole and intercropped treatments at desiccation time in all the three years. Also, no significant shattering was noticed for either of these crops.

\subsubsection{Faba Bean and Chickpea}

Compared to sole crops, the seed yield of both faba bean and chickpea was drastically reduced in all the three years when intercropped with either lentil or field pea (Table 5). The seed yield in 2015 intercrops was only 15 to $26 \%$ of the sole faba bean and 23 to $41 \%$ of the sole chickpea. The 2016 intercrops produced only 27 to $54 \%$ faba bean seed yield and only 34 to $63 \%$ chickpea seed yield compared to their sole crops. Seed yield of both faba bean and chickpea in the 2017 intercrops ranged from 12 to $55 \%$ of their sole crops.

As expected, the faba bean and chickpea seed yield in the 2016 and 2017 intercrops tended to be greater with their $75 \%$ than $50 \%$ seed rates (Table 5). However, the differences in seed yield with their 75 and $50 \%$ seed rates were significant only for faba bean in 2017. 
The seed yield of both faba bean and chickpea, respectively, was lower when intercropped with field pea (316 and $496 \mathrm{~kg} \mathrm{ha}^{-1}$ ) than with lentil (597 and $861 \mathrm{~kg} \mathrm{ha}^{-1}$ ) in 2015 (Table 5). Similarly, the 2016 yield of both faba bean and chickpea, respectively, was significantly lower when intercropped with field pea (ranged from 1246 to 1447 $\mathrm{kg} \mathrm{ha}^{-1}$ ) than lentil (ranged from 2044 to $2519 \mathrm{~kg} \mathrm{ha}^{-1}$ ). Furthermore, the 2017 yield of faba bean, respectively, was significantly lower when intercropped with field pea (588 and $\left.1134 \mathrm{~kg} \mathrm{ha}^{-1}\right)$ than with lentil (1708 and $2660 \mathrm{~kg}$ $\mathrm{ha}^{-1}$ ). Thus, field pea had more of a negative effect on crop yield of these crops than lentil in all the 3 years.

No significant shattering was noticed for either faba bean or chickpea crops. However, not all the faba bean and chickpea seeds had reached full maturity at desiccation in 2016 and 2017.

\subsubsection{Total Seed Yield}

All the intercrops with lentil produced higher total seed yield compared to the lentil sole crop in the three test years (Table 5). The increase varied from year to year and with the other crop type (faba bean or chickpea) in the intercrops.

The increase in seed yield by the lentil-faba bean intercrops over the sole lentil crop was large and significant in 2016 and 2017, while it was small and not significant in 2015. Actual increase in the total seed yield from lentil-faba bean intercrops over the lentil sole crop was $298(27 \%) \mathrm{kg} \mathrm{ha}^{-1}$ in 2015 , while it averaged $2016(120 \%)$ $\mathrm{kg} \mathrm{ha}^{-1}$ in 2016, and $1930(82 \%) \mathrm{kg} \mathrm{ha}^{-1}$ in 2017. Averaged across the five lentil-faba bean intercrop treatments in three years, the increase in total seed yield by the intercrop over the sole lentil crop was $1639(96 \%) \mathrm{kg} \mathrm{ha}^{-1}$, showing that the lentil-faba bean intercrop almost doubled the total seed yield.

Total seed yield increase by the lentil-chickpea intercrops over the sole lentil crop was large and significant for both 2016 intercrops, while it was relatively smaller and not significant for the one 2015 and both the 2017 intercrops (Table 5). Actual increase from lentil-chickpea intercrops was $327(30 \%) \mathrm{kg} \mathrm{ha}^{-1}$ in 2015 , and it averaged $1747(104) \mathrm{kg} \mathrm{ha}^{-1}$ in 2016, and $269(12 \%) \mathrm{kg} \mathrm{ha}^{-1}$ in 2017. The increase in seed yield from the five intercrops over the sole lentil crops in three years averaged $872(51 \%) \mathrm{kg} \mathrm{ha}^{-1}$, suggesting that total seed yield increase from the lentil-chickpea intercrops was 1.51 times of the lentil sole crops.

The total seed yield data indicated potential for large improvements in total production by intercropping lentils with faba bean or chickpea. The benefit was more pronounced from the faba bean than chickpea intercrops with lentil. Thus increase in total seed yield by lentil intercrops over the sole crop can provide considerable economic benefit.

Compared to the sole field pea crop in 2015, 2016 and 2017, the total seed yield from the field pea intercrops was slightly less for two intercrops (field pea $75 \%+$ chickpea $75 \%$ in 2015 , and field pea $100 \%+$ faba bean $50 \%$ in 2017 ), while it was somewhat more for other field pea intercrop treatments (Table 5). The increase in total seed yield from field pea intercrops over the sole crops was significant for only the field pea $100 \%+$ faba bean $50 \%$ and field pea $100 \%+$ chickpea $50 \%$ in 2016 . Thus, field pea intercrops with faba bean and chickpea did not show a consistent potential for improving seed yield over the sole field pea.

\subsection{Land Equivalent Ratio (LER)}

\subsubsection{LER of Individual Crops in Intercrops}

The LER of individual crops in the intercrops reflect relative seed yield from intercrops when compared to the sole crops (intercrop yield/sole crop yield). In the absence of an effect from the other crop, each crop in an intercrop can be expected to produce seed yield based on the seeding rate. Therefore, the expected LER for each crop was considered to reflect the seeding rates in the tested intercrops; i.e., $1.00,0.75$ and 0.50 for the $100 \%, 75 \%$ and $50 \%$ seeding rates, respectively. A different LER than the seed rate used in intercrop indicates that yield of a crop improved or declined when introduced into an intercropping situation.

Table 6. Land equivalent ratio (LER) for the lentil/field pea $\left(\mathrm{LER}_{1}\right)$ and faba bean/chickpea $\left(\mathrm{LER}_{2}\right)$ from their sole and intercropped stands in 2015, 2016 and 2017. The $\mathrm{LER}_{\mathrm{T}}$ for these stands is the sum of $\mathrm{LER}_{1}$ and $\mathrm{LER}_{2}$

\begin{tabular}{llll}
\hline Crop \& Seed Rate\% & 2015 & 2016 & 2017 \\
\hline
\end{tabular}




\begin{tabular}{|c|c|c|c|c|c|c|c|c|c|}
\hline & $\mathrm{LER}_{1}$ & $\mathrm{LER}_{2}$ & LER $_{\mathrm{T}}$ & $\mathrm{LER}_{1}$ & $\mathrm{LER}_{2}$ & $\mathrm{LER}_{\mathrm{T}}$ & $\mathrm{LER}_{1}$ & $\mathrm{LER}_{2}$ & $\mathrm{LER}_{\mathrm{T}}$ \\
\hline Faba Bean $100 \%$ & 0.00 & 1.00 & 1.00 & 0.00 & 1.00 & 1.00 & 0.00 & 1.00 & 1.00 \\
\hline Chickpea $100 \%$ & 0.00 & 1.00 & 1.00 & 0.00 & 1.00 & 1.00 & 0.00 & 1.00 & 1.00 \\
\hline Lentil $100 \%$ & 1.0 & 0 & 1.0 & 1.0 & 0 & 1.0 & 1.00 & 0 & 1.0 \\
\hline Lentil $100 \%+$ Faba Bean $50 \%$ & $\mathrm{n} / \mathrm{a}^{1}$ & $\mathrm{n} / \mathrm{a}$ & $\mathrm{n} / \mathrm{a}$ & 0.92 & 0.44 & 1.37 & 0.93 & 0.36 & 1.29 \\
\hline Lentil $75 \%+$ Faba Bean $75 \%$ & 0.77 & 0.29 & 1.01 & 0.82 & 0.54 & 1.36 & 0.85 & 0.56 & 1.41 \\
\hline Lentil100\%+Chickpea $50 \%$ & $\mathrm{n} / \mathrm{a}$ & $\mathrm{n} / \mathrm{a}$ & $\mathrm{n} / \mathrm{a}$ & 0.81 & 0.60 & 1.41 & 1.09 & 0.13 & 1.22 \\
\hline Lentil75\%+Chickpea $75 \%$ & 0.51 & 0.39 & 0.90 & 0.64 & 0.63 & 1.27 & 0.98 & 0.20 & 1.19 \\
\hline Field Pea $100 \%$ & 1.0 & 0 & 1.0 & 1.0 & 0 & 1.0 & 1.0 & 0 & 1.0 \\
\hline Field Pea $100 \%+$ Faba Bean $50 \%$ & $\mathrm{n} / \mathrm{a}$ & $\mathrm{n} / \mathrm{a}$ & $\mathrm{n} / \mathrm{a}$ & 0.81 & 0.28 & 1.09 & 0.84 & 0.21 & 0.97 \\
\hline Field Pea75\%+Faba Bean75\% & 0.93 & 0.16 & 1.09 & 0.72 & 0.31 & 1.03 & 0.81 & 0.24 & 1.04 \\
\hline Field Pea $100 \%+$ Chickpea $50 \%$ & $\mathrm{n} / \mathrm{a}$ & $\mathrm{n} / \mathrm{a}$ & $\mathrm{n} / \mathrm{a}$ & 0.88 & 0.34 & 1.22 & $\mathrm{n} / \mathrm{a}$ & $\mathrm{n} / \mathrm{a}$ & $1.02^{2}$ \\
\hline Field Pea $75 \%+$ Chickpea $75 \%$ & 0.72 & 0.26 & 0.97 & 0.71 & 0.40 & 1.10 & $\mathrm{n} / \mathrm{a}$ & $\mathrm{n} / \mathrm{a}$ & $1.05^{2}$ \\
\hline$L S D 5 \%$ & 0.134 & 0.058 & 0.082 & 0.179 & 0.082 & 0.194 & 0.133 & 0.068 & 0.138 \\
\hline$C V, \%$ & 10.8 & 6.2 & 5.7 & 14.9 & 5.3 & 11.7 & $7.0 t$ & 10.3 & 8.6 \\
\hline$p$-value & 0.001 & $<0.001$ & 0.009 & 0.003 & $<0.001$ & $<0.001$ & $<0.001$ & $<0.001$ & $<0.001$ \\
\hline
\end{tabular}

Note. ${ }^{1} \mathrm{n} / \mathrm{a}$ refers to not applicable or treatment not tested.

${ }^{2}$ The LER $_{\mathrm{T}}$ for these 2 treatments was calculated by dividing the field pea sole crop yield with total seed yield from the field pea intercrops (as LER for each crop was not calculated).

\section{(1) Lentil and Field Pea $\left(\mathrm{LER}_{1}\right)$}

The LER 1 values of lentil and field pea in the 2015 intercropping treatments were significantly lower than 1.00 , except for the field pea $75 \%+$ faba bean $75 \%$ intercrop (Table 6). But based on seeding rate of $75 \%$ in the

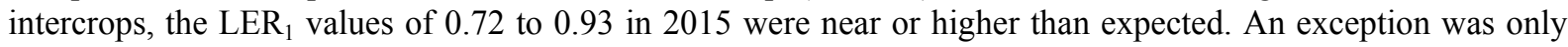
$0.51 \mathrm{LER}_{1}$ in the lentil75\%+chickpea75\% intercrop. Both lentil and field pea at the $100 \%$ seeding rate had less than expected $1.00 \mathrm{LER}_{1}$ (ranged from 0.81 to 0.92 ) in 2016, but with significant reduction occurred only for the lentil100\%+chickpea $50 \%$ and field pea $100 \%+$ faba bean $50 \%$. The $75 \%$ seeding rate intercrop $\mathrm{LER}_{1}$ values were not as good as the $100 \%$ seeding rate (ranged from 0.64 to 0.82 ), but they were no different than the expected $0.75 \mathrm{LER}_{1}$. The 2017 lentil intercrops showed LER ${ }_{1}$ values that were near the expected $1.00(0.93$ and 1.09$)$ for the $100 \%$ seed rate, and above the expected $0.75(0.85$ and 0.98$)$ for the $75 \%$ seeding rate. The 2017 field pea intercrops showed significantly lower than $1.00 \mathrm{LER}_{1}$ values, though the $0.81 \mathrm{LER}_{1}$ for the field pea $75 \%+$ faba bean $75 \%$ was above the expected $0.75 \mathrm{LER}_{1}$ for the $75 \%$ seeding rate.

\section{(2) Faba Bean and Chickpea $\left(\mathrm{LER}_{2}\right)$}

The $\mathrm{LER}_{2}$ values for the faba bean and chickpea were much below their sole crops in all the three years, as well as lower than expected $(0.75$ or 0.50$)$ based on their $75 \%$ and $50 \%$ seed rates, except for a $0.60 \mathrm{LER}_{2}$ for the lentil100\%+chickpea50\% intercrop in 2016 (Table 6).

The $\mathrm{LER}_{2}$ values for faba bean and chickpea in the 2015 intercrops were much lower than expected 0.75 for their $75 \%$ seeding rate. In 2016, the $\mathrm{LER}_{2}$ values for the lentil intercrops with faba bean and chickpea were close to the expected ( 0.44 and 0.60$)$ for the $50 \%$ seeding rate and somewhat lower than expected $(0.54$ and 0.63$)$ for the $75 \%$ seeding rate. When intercropped with field pea in 2016 , the $\mathrm{LER}_{2}$ values for faba bean and chickpea were much lower than the $50 \%(0.28$ and 0.34$)$ and $75 \%$ (0.31 and 0.40$)$ seeding rates. Like 2015, the $\mathrm{LER}_{2}$ values of faba bean and chickpea in 2017 intercrops were much lower than their seeding rates, i.e., 0.12 to 0.36 values for the $50 \%$ seed rate and 0.20 to 0.56 values for the $75 \%$ seed rate treatments.

In 2015 , the $\mathrm{LER}_{2}$ values were better when faba bean and chickpea were intercropped with lentil ( 0.29 and 0.39$)$ than with field pea ( 0.16 and 0.26$)$. The $\mathrm{LER}_{2}$ values for both faba bean and chickpea in 2016 were significantly greater when intercropped with lentil ( 0.44 to 0.63$)$ than when intercropped with field pea $(0.28$ to 0.40$)$. The 2017 $\mathrm{LER}_{2}$ values of faba bean were also lower in intercrops with field pea (0.12 and 0.24$)$ than with lentil $(0.36$ and 0.56). The above mentioned faba bean and chickpea $L_{E R}$ values in different years suggests a more severe negative effect from field pea than from lentil in intercrops, apparently due to the more competitive growth ability of field pea than lentil.

3.5.2 Total LER $\left(\mathrm{LER}_{\mathrm{T}}\right)$ for Intercrops 
The $\mathrm{LER}_{\mathrm{T}}\left(\mathrm{LRT}_{\mathrm{T}}=\mathrm{LER}_{1}+\mathrm{LER}_{2}\right)$ reflects the weighted seed yield of the crops in an intercrop. Greater than one (> 1) $\mathrm{LER}_{\mathrm{T}}$ indicates that out-yielding is occurring with intercropping, and the intercrop is more productive than the sole crop of component crop (i.e., less land requirement with intercropping compared to sole crops).

In 2015, there was very little gain in $\mathrm{LER}_{\mathrm{T}}$ values from the intercrops, due to much lower $\mathrm{LER}_{2}$ values of the faba bean and chickpea in intercrops compared to their $75 \%$ seed rates (Table 6). Unlike 2015, $\mathrm{LER}_{\mathrm{T}}$ values for the lentil intercrops in 2016 and 2017 were always significantly greater than sole lentil. But the field pea intercrops in 2016 and 2017 did not show significant improvement over the sole field pea crop, except for the field pea $100 \%+$ chickpea $50 \%$ in 2016.

The $\mathrm{LER}_{\mathrm{T}}$ values were greater for lentil (1.27 to 1.41) than field pea (1.03 to 1.22) in 2016 intercrops. This was also observed in 2017 intercrops, with the $\mathrm{LRT}_{\mathrm{T}}$ values ranging from 1.19 to 1.41 for the lentil intercrops and ranging from 0.97 to 1.04 for the field pea intercrops. When the 2016 and 2017 data were combined, the total gain in LER values averaged 1.32 for the lentil intercrops and 1.07 for the field pea intercrops. The gain in $\mathrm{LER}_{\mathrm{T}}$ values was similar for the faba bean (1.10 to 1.41, with an average of 1.20) and chickpea (1.10 to 1.41, with an average of 1.24) intercrops.

\section{Discussion}

From literature review, Lithaurugidis et al. (2011) stated that intercropping makes more efficient use of resources on a land base due to the combination of complimentary crops with different rooting ability, canopy structure, height, lodging resistance, nutrient requirements and growing periods. As a result, intercropping improves yield, soil fertility, nutrient uptake and concentration, seed yield, and financial stability, while reducing input costs, lodging, pest pressure and the risk of crop failure. An additional consideration would be the promotion of soil conservation and sustainability due to the increase in the number of crops in rotation. Considerable research information is available in literature on intercropping legumes crops with non-legume crops, but information on the performance of intercropping only legume crops together is for tropical conditions only.

\subsection{Plant Counts, Height and Lodging}

Plant counts were less than expected in the intercrops (based on the chosen seeding rates) for lentil and field pea in some treatments and for faba bean and chickpea in most of the treatments (Table 3). Relatively greater plant count reductions for faba bean and chickpea in the intercropped plots could have been due to their deeper seeding depth. However, no apparent reason could be assigned to plant count reduction of lentil and field pea in some intercrop treatments. The results of the present study suggest that higher than target seeding rates could be useful to obtain proper stand establishment in intercrops, especially for deeper seeded crops.

For plant height, the lack of any consistent effect of intercropping on lentil and field pea compared to observed reduction in plant height of faba bean and chickpea (Table 4), was likely due to the deeper seeding depth of faba bean and chickpea and the relatively slow growth of these longer growing season crops.

Reduced lodging of lentil and field pea in the intercrops when compared to the crops being grown alone in 2016 and 2017 indicates that intercropping could provide better harvesting conditions when crops that have a tendency to lodge are combined with other crops with better stem strength. An important reason for intercropping has been the increased stand ability of crops with weak stem strength and tendency to lodge (Horwith, 1985). Improved harvest ability of crops from intercropping cereals with field pea (Szczukowski, 1989), wheat with lentil (Carr et al., 1995), flax (Linum usitattissinum L.) with lentil (Cowell et al., 1989), and the combination of forage crops (Assefa \& Ledin, 2001) have been previously reported.

\subsection{Seed Yield}

Seed yield of the individual crops across the study years was observed to be lower in the intercrops than the corresponding sole crops, although not always significantly lower (Table 5). This was expected due to the lower than $100 \%$ seeding rates for lentil and field pea in some intercrops $(75 \%)$ and for faba bean and chickpea in all intercrops ( 75 or $50 \%$ ). Given that the total seeding rate was always greater in the intercrops ( 150 or $175 \%$ of the sole crop), the increased competition between plants reduced the yield of each crop in intercrops. Canola-field pea intercrops in Saskatchewan had seed yield of $81-84 \%$ for field pea and $56-69 \%$ for canola (Malhi, 2012). Katyama et al. (1995) reported lower nitrogen yield of groundnuts when intercropped with pigeon pea.

Seed yield reduction in intercrops was more severe for faba bean and chickpea compared to lentil and field pea (Table 5). Similar to plant height, seed yield reduction was likely due to the deeper seeding depth and slower growth rate of faba bean and chickpea. More severe yield reduction for faba bean and chickpea when intercropped with field pea as compared to lentil is expected due to the comparatively faster growth rate and higher competitive ability of field pea. 
The differences in performance of various crops when intercropped is supported by results from earlier studies. Malhi (2012) observed more severe seed yield reduction for canola (31-44\%) than field pea (16-19\%) in the canola-field pea intercrops. In soybean-pigeon pea intercrops, the relative yield, relative nitrogen yield and relative phosphorus yield were reduced for pigeon pea but not for soybean, indicating that soybean was a stronger competitor than pigeon pea (Ghosh et al., 2006). They surmised that fast growing soybean exhausted the soil nitrogen quickly and slow growing pigeon pea suffered from nitrogen deficiency.

Total seed yield results from lentil intercrops showed substantial increase (averaged 96\%) over the sole lentil crop, which could lead to economic benefits, though the benefit is likely to depend on the growing conditions and crop type (Table 5). Unlike lentil, the increase in total seed yield by field pea intercrops over the sole field pea was not consistent.

Similar to our results, the benefit from legume-legume intercrops in tropical areas was found to vary with the crops being intercropped and the sole crop being compared. The soybean-pigeon pea intercrop produced 10 and $51 \%$ higher total yield over the sole pigeon pea and sole soybean, respectively; and had higher energy output, and energy use efficiency compared to sole soybean but not sole pigeon pea (Ghosh et al., 2006). They hypothesized that deep rooting ability of pigeon pea could enhance recycling of nitrogen and phosphorus from deeper soil layers and therefore improved the nutrient use efficiency of the intercrops. Rao and Willey (1980b) noted that indeterminate nature of cowpea reduced the yield of pigeon pea. Nitrogen fixation by the pigeon pea-groundnut intercrop was greater than other intercrops (pigeon pea-soybean and pigeon pea-maize (Zea mays L.)) as well as all the sole crops in these intercrops (Nijra et al., 2012). Compared to sole crops, the $\mathrm{N}$ fixation was greater than both sole groundnut and sole pigeon pea for the pigeon pea-groundnut intercrop, while for the pigeon pea-soybean intercrop it was greater than sole soybean but not sole pigeon pea.

The presence of green faba bean and chickpea seeds in harvested material in 2016 and 2017, especially chickpea, was deemed to be due to the combination of their long growing season requirement and frequent rains throughout the maturation period that supported the indeterminate growth of these crops. In contrast, oilseed-legume intercrops led to improved grain quality in other studies (Zielinska \& Rutkowski, 1988; Szczukowski, 1989).

\subsection{Land Equivalent Ratio (LER)}

As LER of the individual crops reflect the relative seed yield from intercrops and sole crops (intercrop yield/sole crop yield), the LER for each crop ( $\mathrm{LER}_{1}$ and $\left.\mathrm{LER}_{2}\right)$ in intercrops presented a similar trend as the seed yield (Table $6)$.

Total LER values $\left(\mathrm{LER}_{\mathrm{T}}\right)$ of component crops from intercrops $\left(\mathrm{LER}_{1}+\mathrm{LER}_{2}\right)$ compared to sole crops represents weighted seed yield gain from intercrops over the sole crops. The $\mathrm{LER}_{\mathrm{T}}$ values greater than one (1) indicate increased yield from intercrops, suggesting greater land-use efficiency of intercrops than sole crops.

Dry weather in 2015 was considered responsible for the lack of any benefits in LER $_{\mathrm{T}}$ from intercrops (Table 6), as moisture became the growth limiting factor (Table 2). Greater $L_{E R}$ values for all the lentil intercrops over the lentil sole crops in 2016 and 2017 showed a benefit from all the lentil intercrops. Differences in $\mathrm{LER}_{\mathrm{T}}$ results of the intercrops with lentil in 2015 compared to 2016 and 2017 show that climatic conditions can influence the amount of benefits observed from intercropping. Unlike lentil intercrops, lack of $\mathrm{LER}_{\mathrm{T}}$ benefit from field pea intercrops in all three years (except field pea $100 \%+$ chickpea $50 \%$ in 2016), indicated an influence of crop type on the performance of intercrops.

Across 2016 and 2017, the gain in LER $_{\mathrm{T}}$ values averaged 1.32 for lentil intercrops and 1.07 for pea intercrops, showing more potential for intercropping combinations of lentil than field pea. Similar total $\mathrm{LER}_{\mathrm{T}}$ values for faba bean (1.20) and chickpea (1.19) intercrops indicated either of these crops can be used for intercropping with lentil to improve total production from a given area. Overall, the LER $_{\mathrm{T}}$ values showed consistent benefit from intercropping faba bean and chickpea with lentil but not with field pea, with a similar gain from intercropping faba bean and chickpea with lentil.

\subsection{General Discussion}

The results of this study are supported by several other studies on legume intercrops with legumes, oilseeds and cereals. Studies on legume-legume intercrops in tropical climates have been conducted using combinations of pigeon pea, soybean, groundnut and cowpea. The soybean-pigeon pea intercrop produced higher total yield over the both sole crops as well as higher energy output and energy use efficiency over the sole soybean, probably due to deep rooting ability of pigeon pea that enhanced recycling of nitrogen and phosphorus from deeper soil layers (Ghosh et al., 2006). Similarly, the N fixation was greater than both sole groundnut and sole pigeon pea for the pigeon pea-groundnut intercrop, and was greater than sole soybean for the pigeon pea-soybean intercrop (Nijra et 
al., 2012). There was improved $\mathrm{N}$ uptake, enhanced net returns, and a reduction in land requirements with canola-field pea intercrops (Malhi, 2012). Lack of N competition between barley-field pea intercrops was considered to increase the total $\mathrm{N}$ concentration in barley (Knudson et al., 2004). Higher total LER values have been reported with zero-N than $\mathrm{N}$ fertilized intercrops for canola-field pea (Malhi, 2012), barley-field pea (Jensen, 1996; Chen et al., 2004) and rape/canola/mustard-field pea (Aktar et al., 1993; Jetendra \& Mishra, 1999).

The occurrence of higher yields over the respective individual crops in intercropping systems has been attributed to many possible reasons. For the legume-legume intercrops, hypothesized reasons were deep rooting ability of pigeon pea to enhance recycling of nitrogen and phosphorus from deeper soil layers (Ghosh et al, 2006), and lack of competition between pigeon pea and groundnuts in the pigeon pea-groundnut intercrops due to growing habits and planting pattern of component crops (Nijra et al., 2012). It could be due to weed suppression (Carr et al., 1995; Poggio, 2005) and/or lower susceptibility to insects and diseases (Helenius, 1991; Paras \& Chakravorty, 2005; Chen et al., 2007). The more efficient use of resources (e.g., nutrients, water and light) by different crop mixtures over sole crops due to different root systems and symbiotic benefits such as the $\mathrm{N}$ fixed from legumes have been suggested as other reasons (Izaurralde et al., 1992; Hauggaard-Nielsen et al., 2001, 2006). Larger biomass production of intercrops over single crops, apparently due to the enhanced light interception by larger crop canopies, could also help explain the higher yields, especially for canola (Kushwaha \& De, 1987; Morris \& Garrity, 1993).

Another reason for intercropping has been to capture the benefits in a favourable growing season and insure against total crop failure in an unfavourable season by intercropping crops with different growth periods and maturity (Tefara \& Tana, 2002). Added diversity from barley-field pea intercrops was considered to enhance the stability of production by lowering the risk of crop failure (Jensen, 1996; Hauggaard-Nielsen et al., 2001), reduce input costs (fertilizer and pesticides) and increase economic returns (Aktar et al., 1993; Hauggaard-Nielsen \& Jensen, 2001). Probability of a one-time failure from 94 experiments was predicted to happen every 5 years of pigeon pea and 8 years of sorghum (Sorghum bicolor L.) for sole crops, and every 36 years for their intercrops (Rao \& Wiley, 1980a).

The results of this study suggest that intercropping of multiple legumes could be viable under favorable growing conditions where the selected legume crops can be grown and successfully harvested. Intercropping legumes only, suggests improved yield potential without the need for additional $\mathrm{N}$ fertilizer. Thus smaller amount of required fertilizers, in absence of $\mathrm{N}$, could increase fertilizer placement options within the seed rows. Because both crops in the intercrops tested in present study are broadleaf, it provides an opportunity for grassy weed control after seeding and rendering the focus for pre seed weed management on the broadleaf weeds.

Intercropping can present some challenges and there are logistic issues that need consideration. Availability of appropriate equipment for seeding, fertilization, and inoculation requirements of two crops would require attention. The selection of herbicides and additional pesticides could be tricky, although most commercial products if registered for one grain legume crop are likely able to be used on others. Another challenge would be the differences in maturity between the various crops chosen (e.g., lentil and field pea versus faba bean and chickpea), which will usually require a pre-harvest desiccation. Separation of seeds would also need consideration before crop selection. The final aspect to think about would be the potential economic impact from the above mentioned challenges relative to the advantages of adopting an intercrop system on the farm.

\section{Conclusions}

The performance of lentil and field pea intercrops with faba bean and chickpea compared to sole crops of lentil and field pea was influenced by the growing conditions and crop types. In the dry year of 2015, there was very little gain in total seed yield and total LER values from the intercrops, apparently soil moisture became the growth limiting factor. In the 2016 and 2017 seasons with adequate rain, all the lentil, but not field pea, intercrops provided greater total seed yield and total LER values than the sole crops. Thus lentil was better than field pea for intercropping with faba bean and chickpea. The greater gain in total seed yield and total LER values for the lentil than for the pea intercrops in both 2016 and 2017 could be due to relatively more aggressive growth of field pea than lentil. The increase in seed yield of lentil intercrops over sole lentil was greater with faba bean than chickpea, while the increase in total LER was similar with both faba bean and chickpea. Overall, the results indicated a potential for improving total yield from intercrops of lentil with faba bean and chickpea over a sole lentil crop.

\section{References}


Aktar, M. S., Shamsuddin, A. M., Islam, N., \& Rahman, A. R. M. S. (1993). Effects of mixed cropping lentil and mustard at various seeding ratios. Lens, 20, 36-39.

Alberta Agriculture and Forestry. (2018). Current and historical Alberta weather station data viewer. Retrieved from https://agriculture.alberta.ca/acis/alberta-weather-dataviewer.jsp

Assefa, G., \& Ledin, I. (2001). Effect of variety, soil type, and fertilizer on the establishment, growth, forage yield and volunteer intake by cattle by cattle of oats and vetches cultivated in pure stands and mixtures. Animal Feed Sci. Technol, 92, 95-111. https://doi.org/10.1016/S0377-8401(01)00242-5

Carr, P. M., Gardner, J. C., Schatz, B. G., Zwinger, S. W., \& Guldan, S. J. (1995). Grain yield and weed biomass of a wheat-lentil intercrop. Agron. J., 87, 574-579. https://doi.org/10.2134/agronj1995.0002196200870 0030030x

Chen, C., Westcott, M., Neil, K., Wichmann, D., \& Knox, M. (2004). Row configuration and nitrogen application for barley-pea intercropping in Montana. Agron. J., 96, 1730-1738. https://doi.org/10.2134/ agronj2004.1730

Chen, Y., Zhang, F., Tang, L., Zheng, Y., Li, Y., Christie, P., \& Li, L. (2007). Wheat powdery mildew and foliar N concentrations as influenced by $\mathrm{N}$ fertilization and belowground interactions with intercropped faba bean. Plant Soil, 291, 1-13. https://doi.org/10.1007/s11104-006-9161-9

Cowell, L.E., Bremer, E., \& van Kessel, C. (1989). Yield and N-2 fixation of pea and lentil as affected by intercropping and N application. Can. J. Soil Sci., 69, 243-251. https://doi.org/10.4141/cjss89-025

Ghosh, P. K., Mohanty, M., Bandayopadhy, K. K., Painuli, D. K., \& Misra, A. K. (2006). Growth, competition, yields advantage and economics in soybean/pigeon pea intercropping system in semi-arid tropics of India II. Effect of nutrient management. Field Crops Research, 96, 90-97. https://doi.org/10.1016/j.fcr.2005.05.010

Gylling Data Management Inc. (2015). ARM research management software version 2015, copyright 2015. Brookings, SD, USA. Retrieved from http://www.gdmdata.com

Hauggaard-Nielsen, H., \& Jensen, E. S. (2001). Evaluating pea and barley cultivars for complementarity in intercropping at different levels of soil N availability. Field Crops Res., 72, 185-196. https://doi.org/ 10.1016/S0378-4290(01)00176-9

Hauggaard-Nielsen, H., Ambus, P., \& Jensen, E. S. (2001). Temporal and spatial distribution of roots and competition for nitrogen in pea-barley intercrops-A field study employing 32P technique. Plant Soil, 236, 63-74. https://doi.org/10.1023/A:1011909414400

Hauggaard-Nielsen, H., Andersen, M. K., Jørnsgaard, B., \& Jensen, E. S. (2006). Density and relative frequency effects on competitive interactions and resource use in pea-barley intercrops. Field Crops Res., 95, 256-267. https://doi.org/10.1016/j.fcr.2005.03.003

Helenius, J. (1991). Insect numbers and pest damage in intercrops vs. monocrops: concepts and evidence from a system of faba bean, oats and Rhopalosiphum padi (Homoptera, Aphididae). J. Sust. Agric., 1, 57-80. https://doi.org/10.1300/J064v01n03_06

Horwith, B. (1985). A role for intercropping in modern agriculture. Bio Sci., 35, 286-291. https://doi.org/ $10.2307 / 1309927$

ICRISAT/MAI. (2000). Cost-effective soil fertility management options for smallholder farmers in Malawi (pp. 1-24). Bulawayo, Zimbabwe: ICRISAT; Lilongwe, Malawi: Ministry of Agriculture and Irrigation.

Izaurralde, R. C., McGill, W. B., \& Juma, N. J. (1992). Nitrogen fixation efficiency, interspecies N transfer, and root growth in barley-field pea intercrop on a Black Chernozemic soil. Biol. Fertil. Soils, 13, 11-16. https://doi.org/10.1007/BF00337231

Jensen, E. S. (1996). Grain yield, symbiotic $\mathrm{N}_{2}$ fixation and interspecific competition for inorganic $\mathrm{N}$ in pea-barley intercrops. Plant Soil, 182, 25-38. https://doi.org/10.1007/BF00010992

Jetendra, K., \& Mishra, J. P. (1999). Influence of planting pattern and fertilizers on yield and yield attributes and nutrient uptake in pea/mustard intercropping system. Ind. J. Pulses Res., 12, 38-43.

Katyama, K., Ito, O., Matsunanga, R., Adu-Gyamfi, J. J., Rao, T. P., Anders, M. M., \& Lee, K. K. (1995). Nitrogen balance and root behaviour in four pigeon pea intercropping systems. Kluwer Academic Publishers. Fertilizer Res., 42, 315-319. https://doi.org/10.1007/BF00750523 
Knudson, M. T., Hauggaard-Nielsen, H., Jørnsgaard, B., \& Jensen, E. S. (2004). Comparison of interspecific competition and $\mathrm{N}$ use in pea-barley, faba bean-barley and lupin-barley intercrops grown at two temperate locations. J. Agric. Sci., 142, 617-627. https://doi.org/10.1017/S0021859604004745

Kushwaha, B. L., \& De, R. (1987). Studies of resource use and yield of mustard and chickpea grown in cropping systems. J. Agric. Sci., Cambridge, 108, 487-495. https://doi.org/10.1017/S0021859600079533

Lithourgidis, A. S., Dordas, C. A., Damalas, C. A., \& Vlachostergios, D. N. (2011). Annual intercrops: an alternative pathway for sustainable agriculture. Aust J. Crop Sci., 5(4), 396-410.

Malhi, S. S. (2012). Improving crop yield, $N$ uptake and economic returns by intercropping barley or canola with pea. Agricultural Sciences, 3(8), 1023-1033. https://doi.org/10.4236/as.2012.38124

Martin, M. P. L. D., \& Snaydon, R. W. (1982). Root and shoot interactions between barley and beans when intercropped. J. Appl. Ecol., 19, 263-272. https://doi.org/10.2307/2403009

Morris, R. A., \& Garrity, D. P. (1993). Resource capture and utilization in intercropping. Water Field Crops Res., 34, 303-317. https://doi.org/10.1016/0378-4290(93)90119-8

Nijra, K. O. W., Nalivata, P. C., Kanyama-Phiri, G. Y., \& Lowole, M. W. (2012). Biological nitrogen fixation in sole and double-up legume cropping systems on the sandy soils of Kasungu, Central Malawi. J. Soil Sci. and Env. Management, 3(9), 224-230.

Paras, N., \& Chakravorty, S. (2005). Effect of intercropping on the infestation of chickpea pod borer [Helicoverpa armigera (Hubner)]. J. Plant Prot. Environ., 2, 86-91.

Poggio, S. L. (2005). Structure of weed communities occurring in monoculture and intercropping of field pea and barley. Agric. Ecosyst. Environ., 109, 48-58. https://doi.org/10.1016/j.agee.2005.02.019

Rao, M. R., \& Wiley, R. W. (1980a). Preliminary studies of intercropping combinations based on pigeon pea or sorghum. Exp. Agr., 16, 29-39. https://doi.org/10.1017/S001447970001067X

Rao, M. R., \& Wiley, R. W. (1980b). Evaluation of yield stability in intercropping: Studies on sorghum/pigeon pea. Exp. Agr., 16, 105-116. https://doi.org/10.1017/S0014479700010796

Schabenberger, O., \& Pierce, F. J. (2001). Contemporary statistical models for the plant and soil sciences. CRC Press, Boca Raton. https://doi.org/10.1201/9781420040197

Soil Classification Working Group. (1998). The Canadian system of soil classification. Agriculture and Agri-Food Canada Publication 1646 (Revised), National Research Council of Canada, Ottawa, ON, Canada.

Szczukowski, S. (1989). Yield and seed quality of field pea grown in mixtures with cereals and in pure stands, Acta Academiae Agriculturae ac Technicae Olstenensis, Agricultura., 47(Suppl. C), 40.

Tafara, T., \& Tana, T. (2002). Agronomic performance of sorghum and groundnut cultivars in sole and intercrop cultivation under semiarid conditions. J. Agron. Crop Sci., 188, 212-218. https://doi.org/10.1046/j.1439037X.2002.00553.X

Zielinska, A., \& Rutkowski, M. (1988). Comparison of productivity of oats, barley and four cultivars of field pea in pure and mixed sowing. Acta Academiae Agriculturae ac Technicae Olstenensis, Agricultura, 46, 113-124.

\section{Copyrights}

Copyright for this article is retained by the author(s), with first publication rights granted to the journal.

This is an open-access article distributed under the terms and conditions of the Creative Commons Attribution license (http://creativecommons.org/licenses/by/4.0/). 